\title{
Synthesis, Spectral Characterization and Crystal Structure of Chlororhodibalamin: A Synthesis Platform for Rhodium Analogues of Vitamin $B_{12}$ and for Rh-Based Antivitamins $B_{12}$
}

\author{
Florian J. Widner ${ }^{\mathrm{a}, 1 \mathrm{a}}$ \\ Christoph Kieninger ${ }^{\mathrm{a}, 1 \mathrm{~b}}$ \\ Klaus Wurst ${ }^{\mathrm{b}}$ \\ Evelyne Deeryc \\ Andrew D. Lawrence ${ }^{c}$ \\ Martin J. Warren ${ }^{c, d}$ \\ Bernhard Kräutler*a (i) \\ a Institute of Organic Chemistry and Center for Molecular Biosciences, \\ University of Innsbruck, Innrain 80/82, 6020 Innsbruck, Austria \\ bernhard.kraeutler@uibk.ac.at \\ ${ }^{b}$ Institute of General, Inorganic and Theoretical Chemistry, University \\ of Innsbruck, Innrain 80/82, 6020 Innsbruck, Austria \\ ' School of Biosciences, University of Kent, Canterbury, CT2 7NJ, United \\ Kingdom \\ d Quadram Institute Bioscience, Norwich Research Park, Norwich, NR4 \\ 7UQ, United Kingdom \\ Published as part of the Special Topic Functional Organic Molecules
}

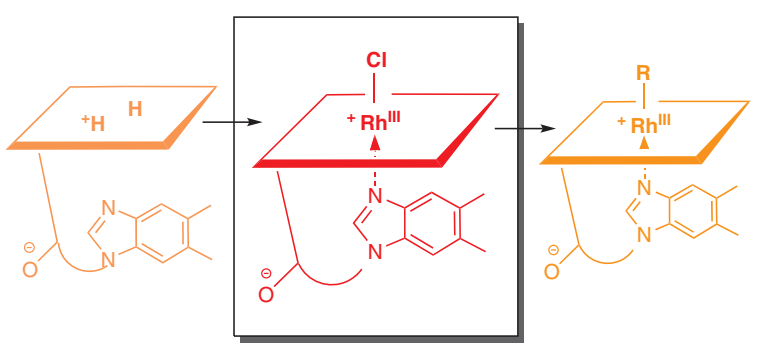

logue of cobalt, rhodium is in prime position in this latter respect, ${ }^{10,12,13}$ although $\mathrm{Rh}$ is not considered a 'bio-metal' and has no known natural biological use. ${ }^{14} \mathrm{Rh}^{\mathrm{III}}$ - and $\mathrm{Co}^{\mathrm{III}}$ corrins are expected to have similar structures, but to differ significantly in their reactivity. ${ }^{10}$ As non-functional structural cobalamin ( $\mathrm{Cbl}$ ) mimics, the corresponding rhodibalamins (Rhbls) have been proposed to specifically qualify as potential 'antivitamins $\mathrm{B}_{12} \cdot{ }^{10,15}$

We describe here a concise synthesis and detailed structural analysis of chlororhodibalamin (ClRhbl), the $\mathrm{Rh}^{\mathrm{III}}$-analogue of the vitamin $\mathrm{B}_{12}$ derivative chlorocobalamin ( $\mathrm{ClCbl}$ ) (Scheme 1). Incompletely characterized ClRhbl was reported in the 1970s by Koppenhagen and co-workers, who also used their ClRhbl preparations as starting materials for the synthesis of other partially characterized rhodibalamins. ${ }^{12}$ For their work, the metal-free $\mathrm{B}_{12}$-ligand hydrogenobalamin (Hbl) was produced (among other isolates) from a laborious guided biosynthesis employing a Chromatium strain grown in the absence of cobalt but supplemented with 5,6-dimethylbenzimidazole (DMB). ${ }^{12}$ More recently, a bioengineered specific biosynthetic production of the metal-free corrin hydrogenobyric acid (Hby) ${ }^{16}$ has opened up a rational entry to the synthesis of transition-metal analogues of vitamin $\mathrm{B}_{12}$, first realized with $\mathrm{Zn} .{ }^{11}$ Subsequently, a highyielding, one-step partial synthesis of $\mathrm{Hbl}$ from Hby has also been developed for the rational alternative preparation of this complete metal-free $B_{12}$-ligand via a chemical-biological path, ${ }^{17}$ in order to make $\mathrm{Hbl}$ available as a versatile starting material for the direct generation of a range of transition-metal analogues of the cobalamins. So far, we have 
used such semisynthetic $\mathrm{Hbl}$ for the synthesis of the previously unknown Ni-analogue of vitamin $B_{12}$, named nibala$\min .{ }^{17}$

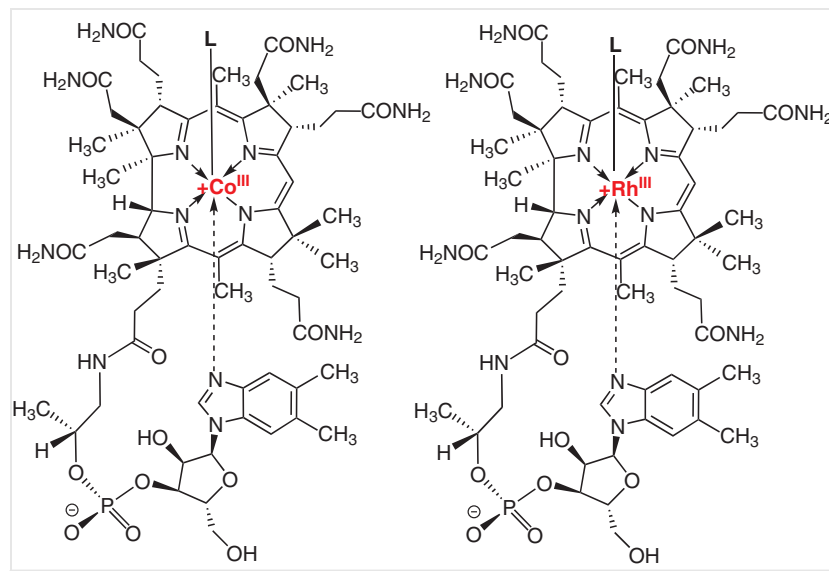

Scheme 1 General structural formula of cobalamins and of rhodibalamins. Left: cobalamins vitamin $B_{12}(L=C N$, cyanocobalamin, $C N C b l)$, chlorocobalamin $(\mathrm{L}=\mathrm{Cl}, \mathrm{ClCbl})$, coenzyme $\mathrm{B}_{12}\left(\mathrm{~L}=5^{\prime}\right.$-deoxy-5'-adenos$\mathrm{yl}$, adenosylcobalamin, $\mathrm{AdoCbl})$, methylcobalamin ( $\mathrm{L}=$ methyl, $\mathrm{MeCbl}$ ). Right: rhodibalamins chlororhodibalamin $(\mathrm{L}=\mathrm{Cl}, \mathrm{ClRhbl})$, adenosylrhodibalamin ( $L=5^{\prime}$-deoxy-5'-adenosyl, AdoRhbl), methylrhodibalamin ( $L=$ methyl, MeRhbl).

As described herein, the semisynthetic metal-free corrin $\mathrm{Hbl}^{17}$ also served as the starting material in a high yielding, one-step synthesis of ClRhbl. The orange-yellow $\mathrm{Rh}^{\mathrm{III}}$ corrin ClRhbl was prepared by the reaction of $\mathrm{Hbl}$ with an excess of $\mu$-dichloro-tetracarbonyl-dirhodium(I) $\left(\left[\mathrm{Rh}(\mathrm{CO})_{2} \mathrm{Cl}_{2}\right){ }^{18-20}\right.$ This substitution labile dimeric $\mathrm{Rh}^{\mathrm{I}}$ reagent was suitable for the kinetically slow metalation of the ring-contracted corrin present in the zwitterionic metalfree $B_{12}$ ligand $\mathrm{Hbl}$, which undergoes epimerization and tautomerization reactions readily. The reaction in a deoxygenated solution in ethylene glycol, heated at $100{ }^{\circ} \mathrm{C}$ (see
Scheme 2 and below for experimental details) made use of optimized preparative conditions modified from those used by Koppenhagen and co-workers (ca. 46\% estimated yield of ClRhbl), ${ }^{12}$ which were based on the original method developed by the Eschenmoser group for the synthesis of a model dicyano-Rh ${ }^{\mathrm{III}}$-corrin. ${ }^{20,21}$ Work-up of the raw ClRhbl in the presence of air, purification by preparative HPLC and crystallization from aqueous acetonitrile furnished crystalline $\mathrm{ClRhbl}$ in $84 \%$ yield (see experimental section).

An aqueous solution of ClRhbl exhibited a UV/Vis-absorption spectrum with characteristic strong maxima at 512 and $485 \mathrm{~nm}$ ( $\alpha$ - and $\beta$-bands) and at $344 \mathrm{~nm}$ ( $\gamma$-band), as similarly reported by Koppenhagen and co-workers (see Figure $1 \mathrm{~A}) .{ }^{12}$ The $\mathrm{CD}$ spectrum of ClRhbl was well structured and featured a sequence of bands with positive and negative signs typical of the natural corrinoids, and as also observed for AdoRhbl, the Rh-analogue of coenzyme $B_{12}$ (Figure 1B). ${ }^{10}$

In a high-resolution ESI mass spectrum of ClRhbl the pseudo-molecular ion $[\mathrm{M}+\mathrm{H}]^{+}$generated the signal of its base peak at $m / z 1408.5104$ [see the Supporting Information (SI), Figure S1], confirming the molecular formula of ClRhbl as $\mathrm{C}_{62} \mathrm{H}_{88} \mathrm{ClN}_{13} \mathrm{O}_{14} \mathrm{PRh}$. A $500 \mathrm{MHz}{ }^{1} \mathrm{H}$ NMR spectrum of the diamagnetic ClRhbl in $\mathrm{D}_{2} \mathrm{O}$ (see Figure 2 ) revealed the characteristic set of four singlets at low field that arise from the aromatic DMB-protons and from HC10, as well as of a doublet $(J=3 \mathrm{~Hz})$ associated with the anomeric ribose proton HC1R. In the high-field part of the NMR spectrum, ten singlets and a doublet were observed, and these were assigned to the eleven methyl groups attached at the corrin ligand at the benzimidazole pseudo-nucleotide and at the isopropanolamine linker group, respectively. The characteristic high-field shift to $0.64 \mathrm{ppm}$ of the singlet of the methyl group $\mathrm{H}_{3} \mathrm{C} 1 \mathrm{~A}$ (for atom numbering see Figure S2 in the SI) gave evidence for shielding by the neighbouring DMB moiety in the 'base-on' structure of this 'inorganic' rhodibala-

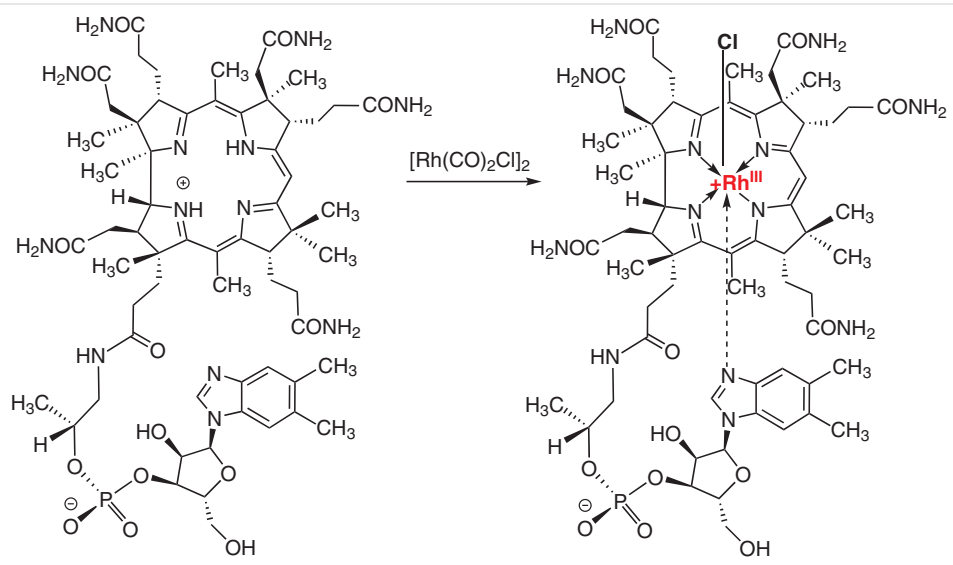

Scheme 2 Partial synthesis of chlororhodibalamin (ClRhbl) from hydrogenobalamin (Hbl) by addition of a deoxygenated solution of $\mathrm{Hbl}$ in ethylene glycol to a carbon monoxide saturated solution of $\left[\mathrm{Rh}(\mathrm{CO})_{2} \mathrm{Cl}\right]_{2}$ (4 equiv) in ethylene glycol, heating the air-protected mixture with stirring to $100{ }^{\circ} \mathrm{C}$ for one hour and aqueous work-up in the presence of air. 


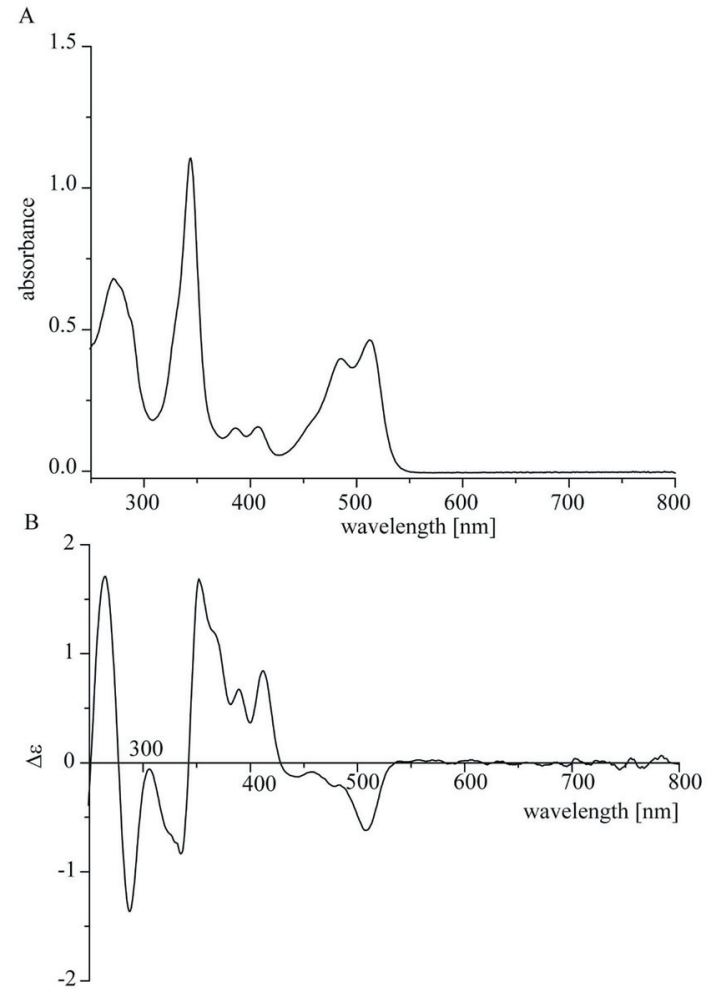

Figure 1 (A) UV/Vis-spectrum of CIRhbl in $\mathrm{H}_{2} \mathrm{O}(c=0.032 \mathrm{mM})$; (B) CD spectrum of $\mathrm{ClRhbl}$ in $\mathrm{H}_{2} \mathrm{O}(c=0.16 \mathrm{mM})$.

min. Extensive ${ }^{1} \mathrm{H},{ }^{1} \mathrm{H}$-homonuclear (COSY and ROESY) as well as ${ }^{1} \mathrm{H},{ }^{13} \mathrm{C}$-heteronuclear (HSQC, HMBC) spectra allowed identification and assignment of the signals of the 73 exchange-resistant protons of $\mathrm{ClRhbl}$ and of all of its 62 carbons (see Figures S2-6 and Table S1 in the SI). The NMR spectral information established the basic three-dimensional structure of $\mathrm{ClRhbl}$ in aqueous solution.

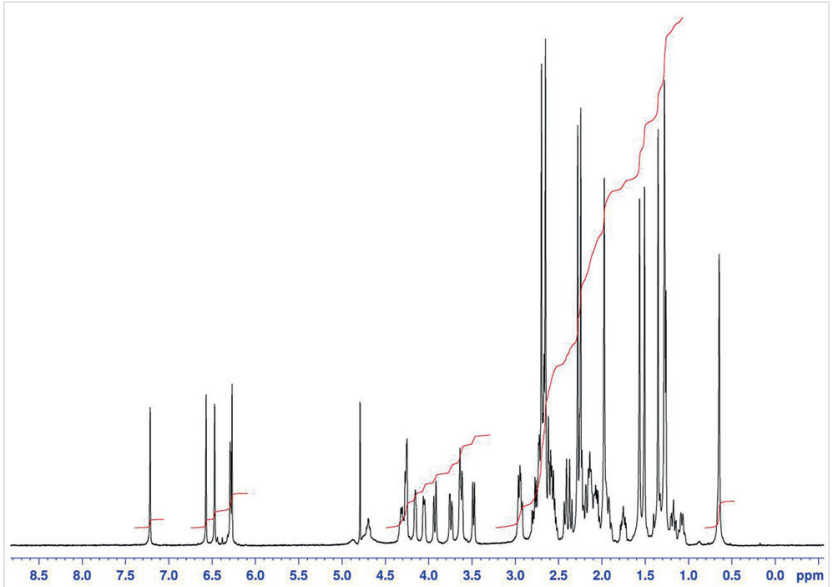

Figure $2500 \mathrm{MHz}^{1} \mathrm{H}$ NMR spectrum of ClRhbl in $\mathrm{D}_{2} \mathrm{O}(\mathrm{c}=4.2 \mathrm{mM}$, $\mathrm{D}_{2} \mathrm{O}, 298 \mathrm{~K}$, with suppression of HDO-signal).
Interestingly, whereas the $\mathrm{Co}^{\mathrm{III}}$-analogue $\mathrm{ClCbl}$ hydrolyses and loses its chloride ion readily (and reversibly in the presence of a high chloride concentration) in aqueous solution, ${ }^{22}$ the analogous hydrolysis of $\mathrm{ClRhbl}$ was not observed at room temperature. The removal of the chloride ion of $\mathrm{Cl}$ $\mathrm{Rhbl}$ can be induced by $\mathrm{AgNO}_{3}$ or by hydride reduction of $\mathrm{ClRhbl}$ to the analogous $\mathrm{Rh}^{\mathrm{I}}$ form (e.g., by sodium borohydride, see below). ${ }^{12} \mathrm{ClRhbl}$ crystallized from aqueous acetonitrile, furnishing single crystals (orthorhombic space group $\mathrm{P} 2{ }_{1} 2_{1} 2_{1}$ ) suitable for analysis by X-ray crystallography. ${ }^{23}$ The highly resolved crystal structure confirmed the NMR-derived 'base-on' nature of ClRhbl, as well as the presence of a chloride ion as axial ligand at the 'upper' $\beta$-face of the $\mathrm{Rh}^{\mathrm{III}}$ centre (Figure 3). Furthermore, it provided detailed insights into the molecular structure of ClRhbl (see Table S2 in the SI), revealing it as isostructural to the cobalt analogue $\mathrm{ClCbl}$ (see Figures S3, S4 in the SI). ${ }^{24}$
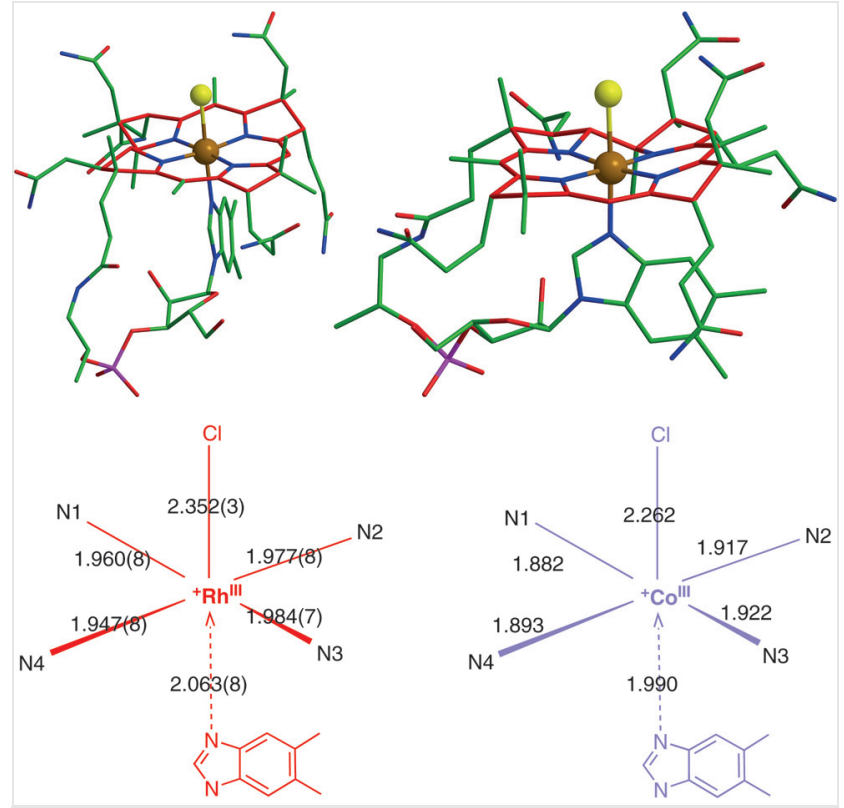

Figure 3 (Top) Structure of CIRhbl from X-ray crystal analysis shown as stick model in two projections, where $\mathrm{C}$-atoms in the core of the corrin moiety are coloured red, and those of the sidechains and of the nucleotide group are coloured green ( $\mathrm{Rh}$ - and $\mathrm{Cl}$-atoms are highlighted as brown and yellow spheres, respectively). (Bottom) Crystallographic lengths (in $\AA$ ) of the bonds around the corrin-bound homologous $d^{6}$ ions $\mathrm{Rh}^{\mathrm{III}}$ and $\mathrm{Co}^{\mathrm{III}}$ in the structures of ClRhbl (left) and chlorocobalamin $(\mathrm{ClCbl})^{24}$ (right), respectively.

When comparing the structures of $\mathrm{ClRhbl}$ and of $\mathrm{ClCbl}^{24}$ (or of a more recently analyzed crystallized ester derivative of $\mathrm{ClCb}^{25}$ ) the four equatorial bonds were longer by an average of about $0.06 \AA$ in the $\mathrm{Rh}^{\mathrm{III}}$-corrin ClRhbl, as roughly expected, based on the larger size of low-spin $\mathrm{Rh}^{\mathrm{III}}$ centres compared to $\mathrm{Co}^{\mathrm{III}}$ ions. ${ }^{26}$ Likewise, the lengths of the axial bonds in ClRhbl, observed as Rh- $\mathrm{Cl}_{\beta}=2.352(3) \AA$ and $\mathrm{Rh}-\mathrm{N}_{\alpha}$ $=2.063(8) \AA$, were longer by about $0.08 \AA$. Similarly, longer axial and equatorial bonds had also been observed when 
comparing the crystal structures of the organometallic pair AdoRhbl and AdoCbl. ${ }^{10}$ Interestingly, the order of the relative lengths of the axial bonds is inverted in both of the 'inorganic' chloro complexes, $\mathrm{ClCbl}\left(\mathrm{Cl}-\mathrm{Co}^{\mathrm{III}}>\mathrm{Co}^{\mathrm{III}}-\mathrm{N}_{\alpha}\right)^{24}$ and ClRhbl $\left(\mathrm{Cl}-\mathrm{Rh}^{\mathrm{III}}>\mathrm{Rh}^{\mathrm{III}}-\mathrm{N}_{\alpha}\right)$, when compared to the analogous organometallic pair adenosylcobalamin (AdoCbl) and its Rh-analogue adenosylrhodibalamin (AdoRhbl), where Ado$\mathrm{Co}^{\mathrm{III}}<\mathrm{Co}^{\mathrm{III}}-\mathrm{N}_{\alpha}$ and Ado- $\mathrm{Rh}^{\mathrm{III}}<\mathrm{Rh}^{\mathrm{III}}-\mathrm{N}_{\alpha}{ }^{10}{ }^{10}$ Remarkably, these observations indicate a quantitatively comparable (structural) trans-influence ${ }^{27}$ of the axial ligands in the rhodibalamins $\mathrm{ClRhbl}$ and AdoRhbl and in the cobalamins $\mathrm{ClCbl}$ and AdoCbl. A roughly similar geometric behaviour of the $\mathrm{Co}^{\mathrm{III}}$ -

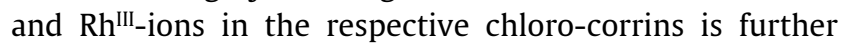
supported by the insignificantly different corrin fold ${ }^{28}$ in $\mathrm{Cl}-$ $\mathrm{Cbl}$ and in $\mathrm{ClRhbl}$, with fold angles of $17.8^{\circ 27,29}$ and $17.4^{\circ}$, respectively. Hence, the previously derived suggestions, based on the detailed structures of the organometallic homologues AdoCbl and AdoRhbl, that the larger $\mathrm{Rh}^{\mathrm{III}}$-ions show a similar (but apparently slightly better) fit for the natural corrin ligand compared to $\mathrm{Co}^{\mathrm{III}}$ ions, and that corresponding $\mathrm{Co}^{\mathrm{III}}$ - and $\mathrm{Rh}^{\mathrm{III}}$-corrins are probably isostructural, ${ }^{10}$ are verified here for the analogous pair of the 'inorganic' $\mathrm{Cl}_{-} \mathrm{Co}^{\mathrm{III}}-$ and $\mathrm{Cl}-\mathrm{Rh}^{\mathrm{III}}$-corrins $\mathrm{ClCbl}$ and $\mathrm{ClRhbl}$ (see Figure $\mathrm{S} 3$ in the SI).

Herein, a high-yield, one-step partial synthesis of crystalline ClRhbl is reported that opens up a door for the direct preparation of a range of rhodibalamins (Rhbls), as previously explored in part by Koppenhagen and co-workers in the 1970s..$^{12}$ One of these, adenosylrhodibalamin (AdoRhbl), the rhodium analogue of coenzyme $B_{12}$, was recently prepared by an intricate combination of biological and chemical synthetic steps. ${ }^{10} \mathrm{~A}$ more direct alternative route to AdoRhbl has been explored here in a preliminary form via the reduction of a deoxygenated (Ar saturated) solution of $\mathrm{ClRhbl}$ in $20 \%$ aqueous $\mathrm{MeOH}$ (6 min), with an excess of sodium borohydride, and subsequent treatment of the yellow solution, with an excess of 5-desoxy-5-iodoadenosine (4 $\mathrm{min}$ ) at room temperature, allowing for the preparation of crystalline AdoRhbl in 63\% isolated yield (Scheme 3; see experimental section and the SI). Along these lines, a highyield synthesis of methyl-rhodibalamin (MeRhbl), the Rhanalogue of the $\mathrm{B}_{12}$-cofactor $\mathrm{MeCbl}$, and the preparation of 'inorganic' analogues of ClRhbl, such as iodorhodiblamin (IRhbl), have also been explored and will be delineated in due course, together with the full characterization of the spectroscopic and structural properties of these Rhbls.

The herein fully characterized $\mathrm{Rh}^{\mathrm{III}}$-corrin ClRhbl promises to constitute a general and efficient synthesis platform to a variety of 'inorganic' and 'organometallic' Rhbls via formal ligand substitution, opening the field for more extensive studies of the chemistry of Rhbls. However, the biological chemistry and activity of ClRhbl itself may also be of specific interest in view of recent insights into the widespread bacterial $\mathrm{B}_{12}$-dependent reductive dehalogenases, ${ }^{30}$ where the formation of a cobalt-halogen bond has been proposed to represent the mechanistically critical step of the dehalogenation reaction in some ${ }^{31}$ (but not all32) of these enzymes.

Preliminary findings suggest a significantly different chemical reactivity of Rhbls from that of the corresponding Cbls. Hence, the Rhbls MeRhbl and AdoRhbl are analogues of MeCbl and of AdoCbl, respectively, yet lacking the specific reactivity of these latter organometallic Cbls. Furthermore, as discussed here, the corresponding Rhbls and Cbls should have similar structures, as was first proposed with the organometallic pair AdoRhbl and AdoCbl. ${ }^{10}$ The de-
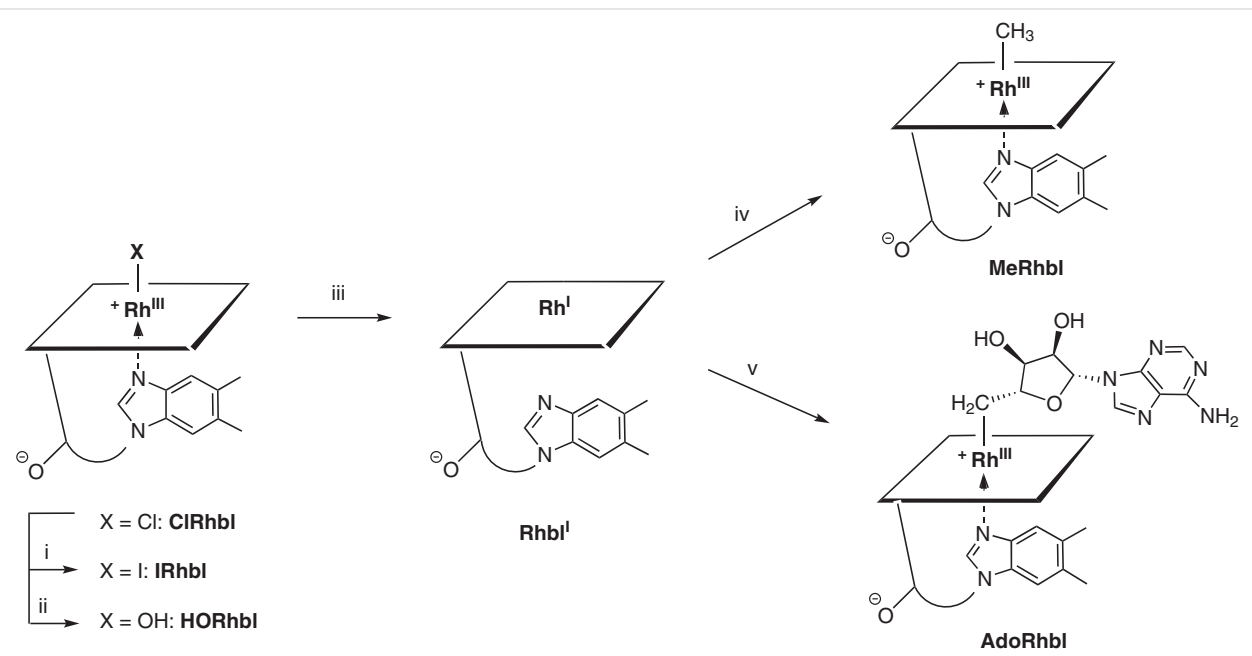

Scheme 3 CIRhbl as synthesis platform for re-functionalized Rhbls. Schematic outline of the partial synthesis at room temperature of 'inorganic' and 'organometallic' Rhbls from CIRhbl by formal ligand substitution, either (i) $\mathrm{KI}$ in $\mathrm{H}_{2} \mathrm{O}$, or (ii) $\mathrm{AgNO}_{3}$ in $\mathrm{H}_{2} \mathrm{O},{ }^{12}$ or (iii) by reduction to the presumed (still minimally characterized) $\mathrm{Rh}^{\prime}$-form of $\mathrm{Rhbl}$ (Rhbl') with $\mathrm{NaBH}_{4}$ in $20 \%$ aq $\mathrm{MeOH}$, followed by (iv) methylation with either Mel ${ }^{12}$ to generate $\mathrm{MeRhbl}$, or ( $v$ ) adenosylation with 5-desoxy-5-iodoadenosine to prepare AdoRhbl. 
duced chemical relationships between corresponding Cbls and Rhbls may be considered to represent a reliable foundation for the suggested, rather general suitability of Rhbls as potential antivitamins $B_{12},{ }^{15,33}$ to be analyzed biochemically and in further biological and biomedical tests. ${ }^{15,34-37}$ Indeed, AdoRhbl and MeRhbl, the organometallic Rh-analogues of AdoCbl and of MeCbl, were shown, ${ }^{10}$ or are presumed, ${ }^{9,34}$ to represent specific inhibitors of AdoCbl- or $\mathrm{MeCbl-dependent} \mathrm{enzymes,} \mathrm{respectively.} \mathrm{In} \mathrm{consequence,}$ AdoRhbl and MeRhbl may act as specific $\mathrm{B}_{12}$ antimetabolites in a range of organisms that use adenosyl- or methylcobamides for a functioning metabolism and gene regulation. The rational entry to a variety of Rhbls via ClRhbl may, thus, open up a path to a new class of potentially highly effective antibiotics and anticancer agents, of particular interest in $\mathrm{B}_{12}$-based chemical biology and (bio)medicine. ${ }^{10,15}$

\section{Experimental section}

5'-Iodo-5'-deoxy-adenosine was prepared as described. ${ }^{38}$ Water was deionized using Epure, Barnstead Co.; acetic acid was distilled over $\mathrm{P}_{2} \mathrm{O}_{5}$ prior to use; acetonitrile and methanol HPLC gradient grade were from BDH Prolabo; $\mu$-dichloro-tetracarbonyldirhodium(I) $\left(\left[\mathrm{Rh}(\mathrm{CO})_{2} \mathrm{Cl}\right]_{2}\right)$, methyl tosylate, potassium dihydrogen phosphate, dipotassium hydrogen phosphate, sodium borohydride, purum, ethane1,2-diol were all from Sigma Aldrich. $1 \mathrm{~g}$ Sep-Pak-C18 Cartridges were purchased from Waters Associates. LiChroprep RP-18 (25-40 $\mu \mathrm{m})$ and TLC aluminium sheets, silica gel 60 RP-18 F254S were from Merck.

UV/Vis spectra were recorded with a Hitachi-U3000, $\lambda_{\max }$ in $\mathrm{nm}(\log$ $\varepsilon)$; CD spectra were recorded with a JASCO J-715 spectrometer $\left(\lambda_{\max }\right.$, $\lambda_{\min }$ and $\lambda_{\mathrm{o}}$ in $\left.\mathrm{nm},(\Delta \varepsilon)\right)$. ${ }^{1} \mathrm{H}$ and ${ }^{13} \mathrm{C}$ NMR spectra were recorded with a $500 \mathrm{MHz}$ Varian Unity Inova instrument, equipped with $5 \mathrm{~mm}$ tripleresonance probe with z-gradients, in $\mathrm{D}_{2} \mathrm{O}, 298 \mathrm{~K}, \delta(\mathrm{HDO})=4.79 \mathrm{ppm}$, coupling constants $J$ in Hz. ESI-HR-MS were recorded with an LTQ-Orbitrap (Thermo-Scientific) positive-ion mode, spray voltage $4.5 \mathrm{kV}$, in $\mathrm{MeOH} / \mathrm{H}_{2} \mathrm{O} 9: 1(\mathrm{v} / \mathrm{v}), m / z$ (relative intensity in \% in reference to basis signal), signals $>5 \%$ are listed. A Hitachi HPLC system with manual sampler was used for chromatography, L-2130 pump, online degasser and diode array detector L2130 (online-UV/Vis Spectra), reverse phase C18 column (YMC, RP18, $250 \times 4.6 \mathrm{~mm}$ ), flow rate of $1.0 \mathrm{~mL}$ $\mathrm{min}^{-1}$; solvent composition $10 \mathrm{mM}$ ammonium acetate (pH7), methanol, linear increase in $40 \mathrm{~min}$ from 8 to $95 \%$ methanol.

\section{Purification of the Rhodibalamin Samples}

Desalting of aqueous solutions was performed using Waters Sep-Pak Plus RP-18 cartridges, which had been conditioned with $10 \mathrm{~mL} \mathrm{MeOH}$ followed by an equilibration/wash with $10 \mathrm{~mL}$ of $\mathrm{H}_{2} \mathrm{O}$. Aqueous solutions of the samples were loaded on the cartridge, which was then washed with $20 \mathrm{~mL}$ of $\mathrm{H}_{2} \mathrm{O}$. The purified samples were eluted with 5$10 \mathrm{~mL}$ of $\mathrm{MeOH}$ (until all coloured material was completely eluted). HPLC conditions were: RP18 Phenomenex $250 \times 4.6 \mathrm{~mm}$, flow $1.0 \mathrm{~mL}$ $\mathrm{min}^{-1}$, phosphate buffer $\mathrm{pH} 7(10 \mathrm{mM}), \mathrm{MeOH}$, linear gradient $2-40 \%$ $\mathrm{MeOH}$ in $20 \mathrm{~min}$, online $\mathrm{UV} / \mathrm{Vis}$ detection at $350 \mathrm{~nm}$.

\section{Chlororhodibalamin (ClRhbl)}

$\mu$-Dichloro-tetracarbonyldirhodium(I) ([Rh(CO) $\left.{ }_{2} \mathrm{Cl}\right]_{2} 6.89 \mathrm{mg}, 17.7$ $\mu \mathrm{mol}$ ) was dissolved in $1.5 \mathrm{~mL}$ ethylene glycol under a carbon monoxide atmosphere. $\mathrm{Hbl}(6.2 \mathrm{mg}, 5.1 \mu \mathrm{mol})^{17}$ was dissolved in ethylene glycol ( $3.5 \mathrm{~mL})$ and the solution was degassed three times by freezepump-thaw with argon. After addition of the solution of $\left[\mathrm{Rh}(\mathrm{CO})_{2} \mathrm{Cl}\right]_{2}$ to the Hbl solution under protection from air, the stirred red-orange reaction mixture was heated to $100{ }^{\circ} \mathrm{C}$ and stirring was continued for one hour. The red-orange reaction solution was cooled to r.t. and deionised water $(5 \mathrm{~mL})$ was added. The red-orange reaction mixture was filtered and desalted with a $1 \mathrm{~g}$ RP-18 cartridge, followed by removal of the solvents by evaporation under reduced pressure on a rotary evaporator. The brown-red residue was dissolved in deionized water and purified by preparative HPLC. Methanol was removed on a rotary evaporator and $\mathrm{ClRhbl}$ was isolated from the remaining yellow-orange aqueous solution by desalting with a $1 \mathrm{~g} \mathrm{RP}-18$ cartridge and removal of solvents. Crystallization from water and acetonitrile gave pure yellow-orange $\mathrm{ClRhbl}(4.5 \mu \mathrm{mol}, 84 \%$ yield $){ }^{23}$

UV/Vis $\left(\mathrm{H}_{2} \mathrm{O}, 0.032 \mathrm{mM}\right): \lambda(\mathrm{nm})(\log \varepsilon)=512(4.16), 485$ (4.09), 407 (3.69), 386 (3.68), 344 (4.54), 271 (4.33) (Figure 1).

$\mathrm{CD}\left(\mathrm{H}_{2} \mathrm{O}, c=0.16 \mathrm{mM}\right): \lambda_{\max }(\Delta \varepsilon), \lambda_{\min }(\Delta \varepsilon)=508(-0.6), 484(-0.2)$, $478(-0.2), 458(-0.1), 442(-0.1), 412(0.8), 400(0.4), 389(0.7), 382$ (0.5), 366sh (1.2), $352(1.7), 335(-0.8), 329(-0.7), 323(-0.6), 306(-0.1)$, $287(-1.4), 265$ (1.7), $242(-0.8) ; \lambda_{0}: 429,342,277,251$ (Figure 1).

${ }^{1} \mathrm{H}$ NMR (500 MHz, $\left.\mathrm{D}_{2} \mathrm{O}, 298 \mathrm{~K}\right): \delta=7.20(\mathrm{~s}, 1 \mathrm{H}, \mathrm{HC} 7 \mathrm{~N}), 6.59(\mathrm{~s}, 1 \mathrm{H}$, HC2N), $6.47(\mathrm{~s}, 1 \mathrm{H}, \mathrm{HC} 4 \mathrm{~N}), 6.29(\mathrm{~d}, J=3 \mathrm{~Hz}, 1 \mathrm{H}, \mathrm{HC} 1 \mathrm{R})$ superimposed by $6.27(\mathrm{~s}, 1 \mathrm{H}, \mathrm{HC} 10), 4.71$ (m, $1 \mathrm{H}, \mathrm{HC} 3 \mathrm{R}), 4.32 / 4.26 / 4.26(\mathrm{~m}, 3 \mathrm{H}$, HC176, HC19, HC2R), 4.16 ( $m, 1 \mathrm{H}, \mathrm{HC}$ ), 4.05 ( $\mathrm{m}, 1 \mathrm{H}, \mathrm{HC} 4 \mathrm{R})$, 3.92/3.74 (AB-system, $J=13 \mathrm{~Hz}, 2 \mathrm{H}, \mathrm{H}_{2} \mathrm{C} 5 \mathrm{R}$ ), 3.65-3.60 (m, $2 \mathrm{H}, \mathrm{HC}$, $\left.\mathrm{H}_{\mathrm{B}} \mathrm{C} 175\right), 3.47$ ( $\left.\mathrm{m}, 1 \mathrm{H}, \mathrm{HC} 13\right), 2.95-2.90$ ( $\left.\mathrm{m}, 2 \mathrm{H}, \mathrm{HC} 18, \mathrm{H}_{\mathrm{A}} \mathrm{C} 175\right), 2.8-$ $2.5\left(\mathrm{~m}, \mathrm{H}_{2} \mathrm{C} 171, \mathrm{H}_{2} \mathrm{C} 181, \mathrm{H}_{2} \mathrm{C} 132, \mathrm{H}_{2} \mathrm{C} 32, \mathrm{H}_{\mathrm{B}} \mathrm{C} 71\right)$ superimposed by $2.70\left(\mathrm{~s}, \mathrm{H}_{3} \mathrm{C} 151\right)$ and $2.65\left(\mathrm{~s}, \mathrm{H}_{3} \mathrm{C} 51\right.$ ), in total $15 \mathrm{H}, 2.43 / 2.36$ (AB-system, $\left.J=18 \mathrm{~Hz}, 2 \mathrm{H}, \mathrm{H}_{2} \mathrm{C} 21\right), 1.8-2.3\left(\mathrm{~m}, \mathrm{H}_{2} \mathrm{C} 31, \mathrm{H}_{\mathrm{A}} \mathrm{C} 71, \mathrm{H}_{2} \mathrm{C} 172\right.$, $\left.\mathrm{H}_{2} \mathrm{C} 131\right)$ superimposed by $2.27\left(\mathrm{~s}, \mathrm{H}_{3} \mathrm{C} 10 \mathrm{~N}\right), 2.24\left(\mathrm{~s}, \mathrm{H}_{3} \mathrm{C} 11 \mathrm{~N}\right)$ and 1.97 (s, $\left.\mathrm{H}_{3} \mathrm{C} 7 \mathrm{~A}\right)$, in total $19 \mathrm{H}, 1.75\left(\mathrm{~m}, 1 \mathrm{H}, \mathrm{H}_{\mathrm{B}} \mathrm{C} 82\right), 1.56\left(\mathrm{~s}, 3 \mathrm{H}, \mathrm{H}_{3} \mathrm{C} 12 \mathrm{~A}\right)$, $1.51\left(\mathrm{~s}, 3 \mathrm{H}, \mathrm{H}_{3} \mathrm{C} 2 \mathrm{~A}\right), 1.4-1-1\left(\mathrm{~m}, \mathrm{H}_{2} \mathrm{C} 177, \mathrm{H}_{\mathrm{A}} \mathrm{C} 82, \mathrm{H}_{\mathrm{B}} \mathrm{C} 81\right)$ superimposed by $1.35\left(\mathrm{~s}, \mathrm{H}_{3} \mathrm{C} 17 \mathrm{~B}\right), 1.28\left(\mathrm{~s}, \mathrm{H}_{3} \mathrm{C} 12 \mathrm{~B}\right)$, in total $10 \mathrm{H}, 1.08(\mathrm{~m}, 1 \mathrm{H}$, $\mathrm{HAC} 81), 0.64\left(\mathrm{~s}, 3 \mathrm{H}, \mathrm{H}_{3} \mathrm{C} 1 \mathrm{~A}\right.$ ) (see Figure 2 and the $\mathrm{SI}$ ).

${ }^{13} \mathrm{C}$ NMR: indirect detection of signals and assignment from heteronuclear ${ }^{1} \mathrm{H},{ }^{13} \mathrm{C}-\mathrm{HSQC}$ and ${ }^{1} \mathrm{H},{ }^{13} \mathrm{C}-\mathrm{HMBC}$ spectra measured at $500 \mathrm{MHz}$ (see Figures S4, S5 and Table S1 in the SI).

HRMS (ESI pos, LTQ-Orbitrap, $\mathrm{MeOH} / \mathrm{H}_{2} \mathrm{O}$ (9:1)): $m / z$ (\%) = 1433.4939 (10), $1432.4937(25), 1431.4963(37), 1430.4928\left(44,[\mathrm{M}+\mathrm{Na}]^{+}\right), 1411.5133(27)$, $1410.5120(61), 1409.5135(82), 1408.5104\left(100,[\mathrm{M}+\mathrm{H}]^{+}\right)$.

HRMS: $m / z$ [M $+\mathrm{H}]^{+}$calcd for $\mathrm{C}_{62} \mathrm{H}_{89} \mathrm{ClN}_{13} \mathrm{O}_{14} \mathrm{PRh}^{+}: 1408.5128$; found: 1408.5104 (see Figure S1 in the SI).

\section{Adenosylrhodibalamin (AdoRbl)}

In a small glass tube, $5^{\prime}$-iodo-5'-deoxyadenosine $(1.47 \mathrm{mg}, 4 \mu \mathrm{mol})$ was dissolved in methanol $(0.29 \mathrm{~mL})$ and deoxygenated for $15 \mathrm{~min}-$ utes with a stream of argon. ClRhbl $(0.5 \mathrm{mg}, 0.36 \mu \mathrm{mol})$ was dissolved in aqueous methanol $(1.47 \mathrm{~mL} 20 \% \mathrm{v} / \mathrm{v})$ and degassed three times by freeze-pump-thaw with argon in a Schlenk flask. To the air-protected ice-water-cooled orange solution of $\mathrm{ClRhbl}, \mathrm{NaBH}_{4}(2.9 \mathrm{mg}, 77 \mu \mathrm{mol})$ was added. After stirring the solution for $6 \mathrm{~min}$ in the dark, the airprotected methanolic solution of 5'-iodo-5'-deoxyadenosine was added and, after 4 minutes, the $\mathrm{pH}$ of the solution was adjusted to $\mathrm{pH}$ 5 with acetic acid. After $90 \mathrm{~min}$, the solvent was evaporated on a rotary evaporator. The residue was dissolved in deionized water and purified by preparative HPLC, separating the reaction mixture of $63 \%$ AdoRhbl, 11\% ClRhbl, 4\% hydroxo-rhodibalamin (HORhbl) and 5\% iodo-rhodibalamin (IRhbl) as well as about $15 \%$ of less polar rhodibalamin side products. The four defined Rhbl fractions (AdoRhbl, HORh$\mathrm{bl}, \mathrm{ClRhbl}$ and IRhbl) were each isolated raw by desalting with a $1 \mathrm{~g}$ RP-18 cartridge and removal of solvents and then tentatively identified by their mass spectral properties. AdoRhbl $(0.36 \mathrm{mg}, 0.22 \mu \mathrm{mol}$, 
63\%) was crystallized from deionized water and acetonitrile and was identified by comparison with authentic material ${ }^{10}$ of $\mathrm{UV} / \mathrm{Vis},{ }^{1} \mathrm{H}$ NMR and HR-ESI-MS-spectra (see the SI).

\section{Funding Information}

Funding by the Austrian Science Fund (FWF, projects No. P-28892 and P30359 to BK), as well as by the Biotechnology and Biological Sciences Research Council (BBSRC, grant number BB/S002197/1 to MJW) and Royal Society (INF|R2|180062 to MJW) is gratefully acknowledged.

\section{Acknowledgment}

We would like to thank Thomas Müller and Martin Tollinger for their help with mass spectrometry and high-field NMR spectroscopy, respectively.

\section{Supporting Information}

Supporting information for this article is available online at https://doi.org/10.1055/s-0040-1707288.

\section{References}

(1) (a) Present address: Sandoz GmbH, Biochemiestrasse 10, 6336 Langkampfen, Austria (b) Present address: Formycon AG, Fraunhoferstraße 15, 82152 Martinsried/Planegg, Germany

(2) Eschenmoser, A. Angew. Chem., Int. Ed. Engl. 1988, 27, 5.

(3) Kräutler, B.; Arigoni, D.; Golding, B. T. Vitamin $B_{12}$ and $B_{12}$-Proteins; Wiley-VCH: Weinheim, 1998.

(4) Banerjee, R. Chemistry and Biochemistry of $B_{12}$; John Wiley \& Sons: New York/Chichester, 1999.

(5) Banerjee, R.; Ragsdale, S. W. Annu. Rev. Biochem. 2003, 72, 209.

(6) Gruber, K.; Puffer, B.; Kräutler, B. Chem. Soc. Rev. 2011, 40, 4346.

(7) Kräutler B., Puffer B., Vitamin B12-Derivatives: Organometallic Catalysts, Cofactors and Ligands of Bio-Macromolecules, In Handbook of Porphyrin Science, Vol. 25; Kadish, K. M.; Smith, K. M.; Guilard, R. World Scientific: Singapore, 2012, 133-265.

(8) Pratt, J. M. The Roles of Co, Corrin and Protein. I. Co-Ligand Bonding and the Trans Effect, In Chemistry and Biochemistry of $B_{12}$; Banerjee, R., Ed.; John Wiley \& Sons: New York, 1999, 73-112.

(9) Koppenhagen, V. B. Metal-Free Corrinoids and Metal Insertion, In $B_{12}$, Vol. 25; Dolphin, D., Ed.; John Wiley \& Sons: New York, 1982, 105-150.

(10) Widner, F. J.; Lawrence, A. D.; Deery, E.; Heldt, D.; Frank, S.; Gruber, K.; Wurst, K.; Warren, M. J.; Kräutler, B. Angew. Chem. Int. Ed. 2016, 55, 11281.

(11) Kieninger, C.; Baker, J. A.; Podewitz, M.; Wurst, K.; Jockusch, S.; Lawrence, A. D.; Deery, E.; Gruber, K.; Liedl, K. R.; Warren, M. J.; Krautler, B. Angew. Chem. Int. Ed. 2019, 58, 14568.

(12) Koppenhagen, V. B.; Elsenhans, B.; Wagner, F.; Pfiffner, J. J. J. Biol. Chem. 1974, 249, 6532.

(13) Bröring, M.; Tejero, E. C.; Pfister, A.; Brandt, C. D.; Torrente, J. J. P. Chem. Commun. 2002, 3058.

(14) da Silva, J. J. R. F.; Williams, R. J. P. The Biological Chemistry of the Elements; Clarendon Press: Oxford, 1991, 400.

(15) Kräutler, B. Chem. Eur. J. 2015, 21, 11280.

(16) Kieninger, C.; Deery, E.; Lawrence, A. D.; Podewitz, M.; Wurst, K.; Nemoto-Smith, E.; Widner, F. J.; Baker, J. A.; Jockusch, S.; Kreutz, C. R.; Liedl, K. R.; Gruber, K.; Warren, M. J.; Kräutler, B. Angew. Chem. Int. Ed. 2019, 58, 10756.
(17) Kieninger, C.; Wurst, K.; Podewitz, M.; Stanley, M.; Deery, E.; Lawrence, A. D.; Liedl, K. R.; Warren, M. J.; Kräutler, B. Angew. Chem. Int. Ed. 2020, https://doi.org/10.1002/anie.202008407.

(18) Cotton, F. A.; Wilkinson, G. Advanced Inorganic Chemistry; Interscience Publishers: New York, 1972.

(19) Collman, J. P.; Hegedus, L. S.; Norton, J. R.; Finke, R. G. Principles and Applications of Organotransition Metal Chemistry; Oxford University Press: Oxford, 1987.

(20) Blaser, H. U.; Winnacker, E. L.; Fischli, A.; Hardegger, B.; Bormann, D.; Hashimoto, N.; Schossig, J.; Keese, R.; Eschenmoser, A. Helv. Chim. Acta 2015, 98, 1845.

(21) Eschenmoser, A. Q. Rev., Chem. Soc. 1970, 24, 366.

(22) Pratt, J. M. Inorganic Chemistry of Vitamin 12; Academic Press: New York, 1972.

(23) X-ray crystal data of ClRhbl have been deposited at the Cambridge Crystallographic Data Centre. CCDC 2017112 contains the supplementary crystallographic data for this paper. The data can be obtained free of charge from The Cambridge Crystallographic Data Centre via www.ccdc.cam.ac.uk/getstructures. See the Supporting Information for the CIF file with respect to the structure analysis of ClRhbl.

(24) Randaccio, L.; Furlan, M.; Geremia, S.; Slouf, M. Inorg. Chem. 1998, 37, 5390.

(25) Hannak, R. B.; Gschösser, S.; Wurst, K.; Kräutler, B. Monatsh. Chem. 2007, 138, 899.

(26) Cordero, B.; Gomez, V.; Platero-Prats, A. E.; Reves, M.; Echeverria, J.; Cremades, E.; Barragan, F.; Alvarez, S. Dalton Trans. 2008, 2832.

(27) Randaccio, L.; Geremia, S.; Nardin, G.; Würges, J. Coord. Chem. Rev. 2006, 250, 1332.

(28) Pett, V. B.; Liebman, M. N.; Murray-Rust, P.; Prasad, K.; Glusker, J. P. J. Am. Chem. Soc. 1987, 109, 3207.

(29) Kratky, C.; Kräutler, B. Molecular Structure of $B_{12}$ Cofactors and other $B_{12}$ Derivatives, In Chemistry and Biochemistry of $B_{12}$; Banerjee, R., Ed.; John Wiley \& Sons: New York/Chichester, 1999, 9-41.

(30) Jugder, B. E.; Ertan, H.; Lee, M.; Manefield, M.; Marquis, C. P. Trends Biotechnol. 2015, 33, 595.

(31) Payne, K. A. P.; Quezada, C. P.; Fisher, K.; Dunstan, M. S.; Collins, F. A.; Sjuts, H.; Levy, C.; Hay, S.; Rigby, S. E. J.; Leys, D. Nature 2015, 517, 513.

(32) Kunze, C.; Bommer, M.; Hagen, W. R.; Uksa, M.; Dobbek, H.; Schubert, T.; Diekert, G. Nat. Commun. 2017, 8, 15858.

(33) Zelder, F.; Sonnay, M.; Prieto, L. ChemBioChem 2015, 16, 1264.

(34) Carmel, R.; Koppenhagen, V. B. Arch. Biochem. Biophys. 1977, $184,135$.

(35) Interest in antivitamins $B_{12}$ (see ref. 33) has induced the Zelder group $^{36}$ to explore a remarkable alternative approach to transition-metal analogues of vitamin $B_{12}$, starting with a 5,6-seco5,6-dioxo-cobalamin from photooxygenolysis of vitamin $\mathrm{B}_{12}{ }^{37}$ In their approach, chemical extrusion of cobalt from the 5,6seco-5,6-dioxo-cobalamin, followed by reductive ring closure, gave a first 5,6-dihydroxy-5,6-dihydrohydrogenobalamin, which was metallated using $\mathrm{NiSO}_{4}$, furnishing a 5,6-dihydroxy5,6-dihydronibalamin.

(36) Brenig, C.; Prieto, L.; Oetterli, R.; Zelder, F. Angew. Chem. Int. Ed. 2018, 57, 16308.

(37) Kräutler, B.; Stepanek, R. Angew. Chem., Int. Ed. Engl. 1985, 24, 62.

(38) Perrone, P.; Daverio, F.; Valente, R.; Rajyaguru, S.; Martin, J. A.; Lévêque, V.; Pogam, S. L.; Najera, I.; Klumpp, K.; Smith, D. B.; McGuigan, C. J. Med. Chem. 2007, 50, 5463. 